\title{
No harmful effects of a selfish B chromosome on several morphological and physiological traits in Locusta migratoria (Orthoptera, Acrididae)
}

\author{
A. J . CASTRO, F. PERFECTTI, M. C. PARDO, J . CABRERO, M. D. LÓPEZ-LEÓN \& \\ J.P. M. CAMACHO* \\ Departamento de Genética, Universidad de Granada, E-18071 Granada, Spain
}

\begin{abstract}
Effects of $\mathrm{B}$ chromosomes on a number of morphological and physiological traits were analysed in 33 controlled crosses performed with Locusta migratoria specimens collected in a natural population close to Granada (Spain). The results show highly significant differences among families, but the absence of any significant effect of Bs on the individuals carrying them. There was, however, a slightly negative relationship between body size, somatic weight and somatic condition of the progeny and the presence of a high number of Bs in the parents, mostly in the mother. This suggests a possible harmful effect of these B chromosomes on egg allocation of substances regulating the initial stages of development. The implications of these findings are discussed in relation to the present understanding of the selfish theory of B chromosome evolution. It is proposed that selfishness and parasitism are two different properties of B chromosomes that should be considered separately.
\end{abstract}

Keywords: B chromosome effects, Locusta migratoria, parasitic B chromosome, selfish B chromosome.

\section{Introduction}

B chromosomes are dispensable supernumeraries which do not recombine with any members of the basic A chromosome set and which have irregular and non-Mendelian modes of inheritance (Jones, 1995). The two main properties determining the maintenance of $\mathrm{B}$ chromosome polymorphisms in natural populations are their transmission efficiency and their effects on carrier fitness. The most frequent situation is that Bs are maintained through accumulation mechanisms (drive) even though they might be harmful to carrier fitness (for review, see Beukeboom, 1994a). In this case, B chromosomes may be considered selfish (if they show drive) and parasitic (if they are harmful to carrier fitness) genetic elements. Whereas B drive has been documented for many Bs (Jones \& Rees, 1982; Jones, 1991, 1995), harmful effects are usually less apparent, even in the most selfish Bs (Beukeboom, 1994b). A possible reason is strong selection for tolerant individuals, which is expected to cause an

*Correspondence. E-mail: jpmcamac@goliat.ugr.es increase in the frequency of individuals less affected by B presence (Shaw \& Hewitt, 1990). However, remnants of these effects that could reveal the parasitic nature of $\mathrm{B}$ chromosomes might remain in natural populations of some species. This is most probable for young B-chromosome systems.

The migratory locust Locusta migratoria shows one of the most impressively widespread B chromosome polymorphisms, as most populations analysed from several continents (Asia, Africa, Australia and Europe) have shown the presence of a B chromosome which in all cases appears to be cytologically the same (for review, see Pardo et al., 1994a). This B chromosome is clearly selfish because it shows drive through both sexes, but the main net accumulation occurs through the female side, because the premeiotic accumulation in males during embryo development (Viseras et al., 1990; Pardo et al., 1995) is partly counteracted by elimination during sexual transmission (Pardo et al., 1994a). The parasitic nature of this $\mathrm{B}$, however, has not been investigated. The present paper deals with the first approach to this matter and thus analyses possible effects of B chromosomes in L. migratoria on several morpho- 
logical and physiological traits, as well as on some other traits directly related to female fitness. The results show that B chromosomes are not strongly parasitic in the population analysed.

\section{Materials and methods}

Adult males and last-instar nymph females of the locust Locusta migratoria were collected in three localities (Armilla, Padul and Las Gabias) close to Granada (Spain) during the 1992 season. When females reached adulthood (isolated from males in order to preserve their virginity), a total of 33 controlled crosses was performed in a room with the temperature controlled at $27^{\circ} \mathrm{C}$ and a $12: 12$ (L:D) photoperiod. Pairs were kept in cages that were daily cleaned and supplied with fresh grass in addition to wheat bran and pieces of orange. Egg-pods were incubated for six days at $28^{\circ} \mathrm{C}$ and then dissected and the numbers of eggs and embryos were counted. Female productivity was measured by the number of eggs or embryos yielded per day (total number of eggs or embryos divided by the number of days between the first and the last egg-pods) and per pod (total number of eggs or embryos divided by the total number of pods), the proportion of ovarioles developing an egg for a given pod (the number of eggs in the pod divided by the number of ovarioles in the female), and egg fertility (embryo/egg ratio). In 18 of the crosses, about half of the egg-pods obtained were incubated until hatching, in order to obtain adult progeny. These nymphs were reared under the same conditions described above for adults. A total of $167 \mathrm{~F}_{1}$ females and $205 \mathrm{~F}_{1}$ males was obtained.

After each cross, the following traits were measured in female parents and adult offspring of both sexes: thorax length and width, tegmina length, hind femur length, hind tibia length, number of antennal segments, body weight, gonad weight, and number of ovarioles or testis follicles. Testes were fixed in 3:1 ethanol-acetic acid but females were injected with $0.05 \%$ colchicine in insect saline solution $6 \mathrm{~h}$ prior to dissection and ovariole fixation. Male and female bodies were stored in $70 \%$ ethanol until measurements could be made. Cytological analyses to determine the number of $\mathrm{B}$ chromosomes in each individual were performed by the C-banding technique described in Camacho et al. (1991).

Ovary size varies enormously during female ontogeny in parallel with the enlargement of the eggs during each cycle of egg-pod laying. To avoid spurious differences in total weight caused by the eggs being at different developmental stages, we used somatic weight (total body weight minus ovary weight) and analysed all male and female offspring at the same age (five days after becoming adult).

Body size in the progeny was defined by means of a Principal Components Analysis (PCA) for the five metrical traits measured (thorax length and width, tegmina length, hind femur length and hind tibia length). The variance explained by PC1 was $64.59 \%$ in females $(N=123)$ and $75.12 \%$ in males $(N=168)$. We defined somatic condition in the progeny as the standardized residuals of a regression of somatic weight on body size (PC1), which was highly significant in both females $\left(r^{2}=0.474\right.$, $\left.F_{1,120}=108.32, P<0.0001\right)$ and males $\left(r^{2}=0.569\right.$, $\left.F_{1,156}=206.25, P<0.0001\right)$.

B chromosome effects were investigated at two levels: (i) direct effects noticed on the carrier individual (i.e. productivity in the female parent, and morphological and physiological traits in the progeny) and (ii) indirect effects of Bs which, present in the parents, might be noticed in the offspring. Because B chromosomes in L. migratoria are mitotically unstable during development, individuals are in fact mosaics for the number of Bs. For this reason, we used the median number of Bs in the gonad as the representative number of Bs of an individual, as justified in Pardo et al. (1995). This involved individually analysing 30 testis follicles per male and 10 ovarioles per female.

\section{Results}

The frequency of $\mathrm{B}$ chromosomes in the population sample analysed was very high, as out of the 66 parent individuals used for the 33 controlled crosses, only three males and two females lacked B chromosomes, implying that the frequency of B-carriers was $92.4 \%$. The mean number of Bs was 1.53 $(\mathrm{SE}=0.15)$ in females and $1.37(\mathrm{SE}=0.21)$ in males. Samples taken at these same localities during 1983 and 1984 had shown that $70-90 \%$ of specimens carried one or more B chromosomes (Viseras, 1986). Such high B frequency is consistent with the strong drive shown by these Bs in both sexes (Pardo et al., 1994a).

\section{Effects of B chromosomes on morphological and physiological traits}

The first approach was to analyse the impact of B chromosomes on the individuals carrying them. Table 1 summarizes the mean values for the different morphological and physiological traits 
measured in the adult offspring obtained. Two-way ANOVA (with family as a random factor and number of Bs as a fixed factor) was performed with data from the five families which yielded 10 or more offspring. Table 2 shows the absence of B effects on any of the seven traits in either sex, but significant differences among families for most of the traits.

The second approach was to investigate the effect that $\mathrm{B}$ presence in parents might have on offspring by a nested ANOVA analysing familial and parental B effects. Parents of the 18 crosses which yielded adult

Table 1 Mean values for four morphological and physiological traits measured in the adult offspring obtained in 18 controlled crosses of Locusta migratoria

\begin{tabular}{llrc}
\hline Trait & Sex of progeny & Mean & SE \\
\hline Somatic weight $(\mathrm{g})$ & Females & 1.656 & 0.071 \\
& Males & 1.045 & 0.050 \\
Gonad weight (g) & Females & 0.129 & 0.038 \\
& Males & 0.054 & 0.005 \\
Number of & Females & & \\
gonad units & (ovarioles) & 96.565 & 1.790 \\
& Males & & \\
Number of & (follicles) & 266.648 & 4.654 \\
antennal segments & Females & 24.855 & 0.126 \\
& Males & 24.798 & 0.062 \\
\hline
\end{tabular}

offspring were grouped into only two categories (1B and 2 or more Bs) because no male and only one female parent lacked Bs, because of the high B frequency in the natural populations analysed (see above). Tables 3 and 4 show that, in accord with the results shown in Table 2, familial effects were highly significant for all traits except for the number of antennal segments, but the presence of B chromosomes in the mother produced slightly significant effects on somatic weight of male and female offspring as well as on the body size of female offspring (Table 3). Likewise, the presence of B chromosomes in the father produced slightly significant effects on the somatic condition of female offspring (Table 4). In all cases, the lower values for these variables in the progeny corresponded to the parents with the higher number of Bs. The probability values, however, became nonsignificant after applying the sequential Bonferroni method.

\section{Effects of B chromosomes on female productivity}

Table 5 shows the mean values for the five variables related to female productivity. All these variables showed normal distributions and the Levene test revealed homogeneity of variances between $0 \mathrm{~B}, 1 \mathrm{~B}$ and $2 \mathrm{~B}+$ females. This allowed the application of the parametric ANOvA that showed the absence of significant differences between the three groups of

Table 2 Two-way anova (with family as a random factor and number of Bs as a fixed factor) performed with the data from the five families of Locusta migratoria that yielded 10 or more offspring

\begin{tabular}{|c|c|c|c|c|c|c|c|c|}
\hline \multirow[b]{2}{*}{ Trait } & \multirow[b]{2}{*}{ Sex } & \multirow[b]{2}{*}{$N$} & \multicolumn{2}{|c|}{ B effect } & \multicolumn{2}{|c|}{ Family effect } & \multicolumn{2}{|c|}{ Interaction } \\
\hline & & & $F$ & $P$ & $F$ & $P$ & $F$ & $P$ \\
\hline Body size (PC I) & $\begin{array}{l}\text { Females } \\
\text { Males }\end{array}$ & $\begin{array}{l}56 \\
57\end{array}$ & $\begin{array}{l}1.604 \\
1.070\end{array}$ & $\begin{array}{l}\text { NS } \\
\text { NS }\end{array}$ & $\begin{array}{r}7.204 \\
23.375\end{array}$ & $\begin{array}{r}0.0006 \\
<0.0001\end{array}$ & $\begin{array}{l}2.305 \\
1.830\end{array}$ & $\begin{array}{l}\text { NS } \\
\text { NS }\end{array}$ \\
\hline Somatic weight & $\begin{array}{l}\text { Females } \\
\text { Males }\end{array}$ & $\begin{array}{l}68 \\
63\end{array}$ & $\begin{array}{l}2.119 \\
0.029\end{array}$ & $\begin{array}{l}\text { NS } \\
\text { NS }\end{array}$ & $\begin{array}{r}7.079 \\
14.259\end{array}$ & $\begin{array}{r}0.0004 \\
<0.0001\end{array}$ & $\begin{array}{l}1.468 \\
0.234\end{array}$ & $\begin{array}{l}\text { NS } \\
\text { NS }\end{array}$ \\
\hline Gonad weight & $\begin{array}{l}\text { Females } \\
\text { Males }\end{array}$ & $\begin{array}{l}68 \\
63\end{array}$ & $\begin{array}{l}1.578 \\
0.674\end{array}$ & $\begin{array}{l}\text { NS } \\
\text { NS }\end{array}$ & $\begin{array}{l}5.054 \\
4.293\end{array}$ & $\begin{array}{l}0.0081 \\
0.0043\end{array}$ & $\begin{array}{l}0.532 \\
1.563\end{array}$ & $\begin{array}{l}\text { NS } \\
\text { NS }\end{array}$ \\
\hline Somatic condition & $\begin{array}{l}\text { Females } \\
\text { Males }\end{array}$ & $\begin{array}{l}56 \\
57\end{array}$ & $\begin{array}{l}0.031 \\
3.433\end{array}$ & $\begin{array}{l}\text { NS } \\
\text { NS }\end{array}$ & $\begin{array}{l}0.005 \\
5.804\end{array}$ & $\begin{array}{l}\mathrm{NS} \\
0.0022\end{array}$ & $\begin{array}{l}2.954 \\
1.603\end{array}$ & $\begin{array}{c}0.045 \\
\text { NS }\end{array}$ \\
\hline Number of gonad units & $\begin{array}{l}\text { Females } \\
\text { Males }\end{array}$ & $\begin{array}{l}56 \\
78\end{array}$ & $\begin{array}{l}0.062 \\
2.634\end{array}$ & $\begin{array}{l}\text { NS } \\
\text { NS }\end{array}$ & $\begin{array}{r}14.895 \\
4.720\end{array}$ & $\begin{array}{r}<0.0001 \\
0.0021\end{array}$ & $\begin{array}{l}0.634 \\
1.148\end{array}$ & $\begin{array}{l}\text { NS } \\
\text { NS }\end{array}$ \\
\hline Testis follicles volume & Males & 79 & 1.261 & NS & 6.679 & 0.0001 & 1.174 & NS \\
\hline $\begin{array}{l}\text { Number of antennal } \\
\text { segments }\end{array}$ & $\begin{array}{l}\text { Females } \\
\text { Males }\end{array}$ & $\begin{array}{l}65 \\
62\end{array}$ & $\begin{array}{l}1.283 \\
0.806\end{array}$ & $\begin{array}{l}\text { NS } \\
\text { NS }\end{array}$ & $\begin{array}{l}0.253 \\
0.239\end{array}$ & $\begin{array}{l}\text { NS } \\
\text { NS }\end{array}$ & $\begin{array}{l}0.673 \\
0.615\end{array}$ & $\begin{array}{l}\text { NS } \\
\text { NS }\end{array}$ \\
\hline
\end{tabular}


Table 3 Analysis of the effect of B number in Locusta migratoria female parents on several morphological and physiological traits of their offspring, by means of a nested ANOvA

\begin{tabular}{|c|c|c|c|c|c|c|c|c|c|c|}
\hline \multirow[b]{3}{*}{ Trait } & \multirow[b]{3}{*}{ Sex } & \multirow[b]{3}{*}{$N$} & \multirow{2}{*}{\multicolumn{3}{|c|}{ Family effect }} & \multirow{2}{*}{\multicolumn{2}{|c|}{ B effect (1 d.f.) }} & \multicolumn{3}{|c|}{$\%$ variance at level } \\
\hline & & & & & & & & & & \\
\hline & & & d.f. & $F$ & $P$ & $F$ & $P$ & Ind. & Fam. & mother \\
\hline \multirow[t]{2}{*}{ Body size (PC I) } & Females & 118 & 14 & 4.753 & $<0.0001$ & 6.448 & 0.0236 & 51.3 & 27.5 & 21.1 \\
\hline & Males & 157 & 15 & 12.669 & $<0.0001$ & 1.858 & NS & 41.6 & 55.2 & 3.2 \\
\hline \multirow[t]{2}{*}{ Somatic weight } & Females & 161 & 13 & 7.009 & $<0.0001$ & 7.183 & 0.0189 & 47.7 & 28.5 & 23.8 \\
\hline & Males & 192 & 15 & 10.461 & $<0.0001$ & 6.768 & 0.0200 & 40.4 & 35.9 & 23.6 \\
\hline \multirow[t]{2}{*}{ Gonad weight } & Females & 161 & 13 & 3.870 & $<0.0001$ & 0.334 & NS & 81.3 & 18.7 & 0 \\
\hline & Males & 192 & 15 & 3.982 & $<0.0001$ & 0.922 & NS & 79.6 & 20.4 & 0 \\
\hline \multirow{2}{*}{$\begin{array}{l}\text { Somatic } \\
\quad \text { condition }\end{array}$} & Females & 118 & 14 & 5.906 & $<0.0001$ & 0.126 & NS & 58.8 & 41.2 & 0 \\
\hline & Males & 157 & 15 & 4.101 & $<0.0001$ & 2.427 & NS & 70.9 & 25.0 & 4.1 \\
\hline \multirow{2}{*}{$\begin{array}{l}\text { Number of } \\
\text { gonad units }\end{array}$} & Females & 154 & 14 & 5.128 & $<0.0001$ & 0.576 & NS & 69.3 & 30.7 & 0 \\
\hline & Males & 201 & 15 & 5.513 & $<0.0001$ & 0.001 & NS & 71.3 & 28.7 & 0 \\
\hline $\begin{array}{l}\text { Testis follicles } \\
\text { volume }\end{array}$ & Males & 123 & 7 & 4.132 & $<0.0010$ & 0.005 & NS & 80.5 & 19.5 & 0 \\
\hline \multirow{2}{*}{$\begin{array}{l}\text { Number of } \\
\text { antennal } \\
\text { segments }\end{array}$} & Females & 158 & 14 & 0.845 & NS & 2.049 & NS & 98.8 & 0 & 1.2 \\
\hline & Males & 199 & 15 & 1.290 & NS & 0.302 & NS & 97.5 & 2.5 & 0 \\
\hline
\end{tabular}

Ind., individual; Fam., family.

Table 4 Analysis of the effect of B number in Locusta migratoria male parents on several morphological and physiological traits of their offspring, by means of a nested ANOvA

\begin{tabular}{|c|c|c|c|c|c|c|c|c|c|c|}
\hline \multirow[b]{3}{*}{ Trait } & \multirow[b]{3}{*}{ Sex } & \multirow[b]{3}{*}{$N$} & \multirow{2}{*}{\multicolumn{3}{|c|}{ Family effect }} & \multirow{2}{*}{\multicolumn{2}{|c|}{ B effect (1 d.f.) }} & \multicolumn{3}{|c|}{$\%$ variance at level } \\
\hline & & & & & & & & & & \\
\hline & & & d.f. & $F$ & $P$ & $F$ & $P$ & Ind. & Fam. & father \\
\hline \multirow[t]{2}{*}{ Body size (PC I) } & Females & 113 & 14 & 6.314 & $<0.0001$ & $<0.001$ & NS & 56.3 & 43.7 & 0 \\
\hline & Males & 149 & 15 & 13.513 & $<0.0001$ & 0.229 & NS & 39.9 & 60.1 & 0 \\
\hline \multirow[t]{2}{*}{ Somatic weight } & Females & 155 & 13 & 10.130 & $<0.0001$ & 0.555 & NS & 52.4 & 47.6 & 0 \\
\hline & Males & 181 & 15 & 14.380 & $<0.0001$ & 0.097 & NS & 43.0 & 57.0 & 0 \\
\hline \multirow[t]{2}{*}{ Gonad weight } & Females & 155 & 13 & 3.323 & $<0.0010$ & 0.179 & NS & 83.2 & 16.8 & 0 \\
\hline & Males & 181 & 15 & 4.362 & $<0.0001$ & 0.232 & NS & 78.3 & 21.7 & 0 \\
\hline \multirow{2}{*}{$\begin{array}{l}\text { Somatic } \\
\quad \text { condition }\end{array}$} & Females & 113 & 14 & 4.520 & $<0.0001$ & 5.626 & 0.0326 & 48.1 & 24.7 & 27.2 \\
\hline & Males & 149 & 15 & 3.763 & $<0.0001$ & 3.668 & NS & 67.5 & 22.5 & 10.0 \\
\hline \multirow{2}{*}{$\begin{array}{l}\text { Number of } \\
\text { gonad units }\end{array}$} & Females & 154 & 14 & 5.128 & $<0.0001$ & 0.576 & NS & 69.3 & 30.7 & 0 \\
\hline & Males & 191 & 15 & 5.707 & $<0.0001$ & 0.243 & NS & 69.6 & 30.4 & 0 \\
\hline $\begin{array}{l}\text { Testis follicles } \\
\text { volume }\end{array}$ & Males & 123 & 7 & 3.990 & $<0.0010$ & 0.254 & NS & 82.0 & 18.0 & 0 \\
\hline \multirow{2}{*}{$\begin{array}{l}\text { Number of } \\
\text { antennal } \\
\text { segments }\end{array}$} & Females & 151 & 14 & 0.851 & NS & 1.192 & NS & 99.6 & 0 & 0.4 \\
\hline & Males & 189 & 15 & 1.422 & NS & 0.262 & NS & 96.2 & 3.8 & 0 \\
\hline
\end{tabular}

Ind., individual; Fam., family. 
Table 5 Descriptive statistics of six productivity-related traits and comparison between $0 \mathrm{~B}, 1 \mathrm{~B}$ and $2 \mathrm{~B}+$ females of Locusta migratoria by means of parametric ANOVA

\begin{tabular}{|c|c|c|c|c|c|c|c|c|c|c|c|}
\hline \multirow[b]{2}{*}{ Trait } & \multicolumn{3}{|c|}{ OB } & \multicolumn{3}{|c|}{ 1B } & \multicolumn{3}{|c|}{$2 \mathrm{~B}+$} & \multicolumn{2}{|c|}{ ANOVA } \\
\hline & Mean & SE & $N$ & Mean & SE & $N$ & Mean & SE & $N$ & $F$ & $P$ \\
\hline Eggs per pod & 40.00 & 1.00 & 2 & 43.71 & 3.20 & 11 & 41.40 & 3.80 & 15 & 0.073 & 0.930 \\
\hline Embryos per pod & 20.67 & 3.33 & 2 & 30.02 & 3.53 & 11 & 23.19 & 3.44 & 15 & 0.827 & 0.449 \\
\hline Egg fertility (embryo/eggs) & 0.519 & 0.096 & 2 & 0.672 & 0.059 & 11 & 0.533 & 0.040 & 15 & 1.859 & 0.177 \\
\hline $\begin{array}{l}\text { Proportion of ovarioles } \\
\text { producing an egg }\end{array}$ & - & - & 0 & 0.416 & 0.048 & 7 & 0.359 & 0.056 & 7 & 0.601 & 0.453 \\
\hline Eggs per day & 3.20 & 0.80 & 2 & 3.74 & 0.43 & 11 & 3.96 & 0.66 & 15 & 0.118 & 0.889 \\
\hline Embryos per day & 1.58 & 0.11 & 2 & 2.51 & 0.37 & 11 & 2.25 & 0.45 & 15 & 0.021 & 0.979 \\
\hline
\end{tabular}

$\mathrm{N}$, number of females; SE, standard error.

females differing for the number of B chromosomes (Table 5).

\section{Discussion}

Effects of B chromosomes have been investigated at many levels in many B systems, and the main conclusion is that they rarely produce visible effects on the external phenotype, but they often cause diverse physiological effects, many detrimental to carrier fitness (for review, see Jones \& Rees, 1982). The present results have shown the absence of significant effects of B chromosome number on several morphological and physiological traits of L. migratoria individuals, and thus suggest that these Bs are mostly innocuous at present in the population analysed. Our results, however, are not conclusive because the extremely high frequency of Bs in the natural population analysed did not allow the use of the $\mathrm{OB}$ class for certain statistical analyses. The possible effect of $B$ presence is thus an open question for future analyses comparing $0 \mathrm{~B}$ individuals with those showing different numbers of Bs, but this needs to be carried out in a population with a lower $\mathrm{B}$ frequency. The problem is that if B frequency is low, then the evolution of B tolerance is unlikely. The possibilities that $\mathrm{B}$ effects are too slight to be detected with the present data, or else that they might be stronger on some traits not analysed in the present report, cannot be ruled out.

The analysis of intergeneration effects, however, has revealed that the progeny of individuals (mainly females) carrying higher numbers of Bs show smaller values for some variables that could be related to fitness (body size, somatic weight and somatic condition). This suggests that, although this selfish B is not parasitic on the developmental stages mainly driven by the egg genotype (as is suggested by the absence of effects on B carriers), it might nevertheless be detrimental during early stages where development is mainly driven by the mother's genotype, interfering with the allocation of nutrients and/or regulatory substances towards the eggs during the prelaying period. Although our results were only weakly significant, they nevertheless suggest a new level of analysis of B effects that has hitherto been ignored, i.e. the transgenerational effect that $\mathrm{B}$ presence in the mother may have on offspring development by interfering with the normal course of oogenesis, a complex process that, in Mahowald's words, is the central preparatory event for embryogenesis (Mahowald, 1972). A similar intergeneration effect has recently been reported in the pseudogamous parthenogenetic planarian Polycelis nigra, where young from mothers with B chromosomes grew slower than those of mothers without Bs (Beukeboom et al., 1998).

Locusta migratoria females are known to obtain male-derived proteinaceous nutrients from the ejaculate which they incorporate into the eggs they lay (Pardo et al., 1994b). One way in which B chromosomes could interfere with early development is thus by influencing the transfer of these substances. This would explain both the paternal and maternal B effects. In addition, the maternal B could directly influence the process of incorporation of mother-derived regulatory substances into the egg before laying. The intergeneration $\mathrm{B}$ chromosome effect could thus operate by decreasing the amount of parental nutrients incorporated into the eggs, as might be expected from the decreasing effect on body size, somatic weight and somatic condition. The present experiments were performed with locusts provided food ad libitum, so that a limitation 
in food supply could perhaps help manifest this effect to a higher degree.

The absence of B effects on female productivity suggests that these selfish elements are well tolerated at present in L. migratoria specimens from the population analysed, at least for the numbers of $\mathrm{B}$ chromosomes tested. This does not rule out the possibility that B chromosomes are harmful in other populations or that they were more harmful in the past. In fact, other B chromosomes in insects seem to lack detrimental effects on carrier fitness, including the most selfish B so far known, i.e. that in the parasitoid wasp Nasonia vitripennis (Beukeboom, 1994b). In the grasshopper Eyprepocnemis plorans, where B chromosomes seem to have been originally selfish but have been neutralized by the host genome, there are no apparent B effects on carrier fitness (López-León et al., 1992; Camacho et al., 1997a,b), and an analysis of traits similar to those analysed in the present report, failed to show any significant B effects (Martín-Alganza et al., 1997). All these findings suggest that, at least in animals living in natural populations, there should be a strong selection for individuals that are more tolerant to B chromosomes. This idea was suggested by Shaw (1984) who stated that 'alleles on the A chromosome set that reduce the selection operating against animals carrying Bs will be selected, as will B chromosomes that are less damaging to their carrier'. As Shaw pointed out, the logical consequence for these B-tolerance alleles is their fixation in populations as Bs increase in frequency. This implies that old B chromosome systems with high B frequency are unlikely to be strongly parasitic, as is the case in L. migratoria.

The existence of many reported B effects in cultivated plants (see Jones \& Rees, 1982) could be explained by the relaxation of natural selection for B tolerance in the benign environmental conditions provided by breeders. In some cases, however, it is also conceivable that harmful B effects are present because of the absence of appropriate genetic variation in B tolerance that is necessary for the operation of natural selection.

The selfish theory of B chromosome evolution (Jones, 1985; Shaw \& Hewitt, 1990) relies heavily on the consideration that $\mathrm{B}$ chromosomes are parasites (Östergren, 1945; Nur, 1977) but, in fact, selfishness and parasitism are two separate properties of B chromosomes, as proved by the existence of selfish Bs that are apparently not parasitic. We propose that these two properties should not be mixed but rather analysed separately for each $\mathrm{B}$ chromosome system through the study of the two main evolution- ary aspects of Bs, viz. B-drive determining their selfishness, and B-effects on carrier fitness determining their parasitism.

\section{Acknow ledgements}

We would like to thank Leo Beukeboom for valuable comments on the manuscript. This study was partially supported by grants from the Dirección General de Enseñanza Superior (no. PB96-1433) and the Plan Andaluz de Investigación, Grupo no. CVI-165 (Spain).

\section{References}

BeukeboOM, L. w. 1994a. Bewildering Bs: an impression of the 1st B-Chromosome Conference. Heredity, 73, 328-336.

BEUKeboom, L. w. 1994b. Phenotypic fitness effects of the selfish B chromosome, paternal sex ratio (PSR) in the parasitic wasp Nasonia vitripennis. Evol. Ecol., 8, 1-24.

BEUKEBOOM, L. W., SEIF, M., PLOWMAN, A. B., DE RIDDER, F. AND MICHIELS, N. K. 1998. Phenotypic fitness effects of $\mathrm{B}$ chromosomes in the pseudogamous parthenogenetic planarian Polycelis nigra. Heredity, in press.

CAMACHO, J. P. M., CABRERO, J., VISERAS, E., LÓPEZ-LEÓN, M. D., NAVAS-CASTILlo, J. AND ALCHE, J. D. 1991. G-banding in two species of grasshoppers and its relationship to $\mathrm{C}, \mathrm{N}$ and fluorescence banding techniques. Genome, 34, 638-643.

CAMACHO, J. P. M., CABRERO, J., LÓPEZ-LEÓN, M. D. AND SHAw, M. W. 1997a. Evolution of a near-neutral B chromosome. In: Henriques-Gil, N., Parker, J. and Puertas, M. J. (eds) Chromosomes Today, vol. 12, pp. 301-318. Chapman and Hall, London.

CAMACHO, J. P. M., SHAW, M. W., LÓPEZ-LEÓN, M. D., PARDO, M. C. AND CABrero, J. 1997b. Population dynamics of a selfish B chromosome neutralized by the standard genome in the grasshopper Eyprepocnemis plorans. Am. Nat., 149, 1030-1050.

JONES, R. N. 1985. Are B chromosomes selfish? In: Cavalier-Smith, T. (ed.) The Evolution of Genome Size, pp. 397-425. Wiley, London.

Jones, R. N. 1991. B-chromosome drive. Am. Nat., 137, $430-442$.

JONES, R. N. 1995. Tansley review no. 85: B chromosomes in plants. New Phytol., 131, 411-434.

JONES, R. N. AND REES, H. 1982. B Chromosomes. Academic Press, New York.

LÓPEZ-LEÓN, M. D., PARDO, M. C., CABRERO, J. AND CAMACHO, J. P. M. 1992. Random mating and absence of sexual selection for B chromosomes in two natural populations of the grasshopper Eyprepocnemis plorans. Heredity, 69, 558-561.

MAHOWALD, A. P. 1972. Ultrastructural observations on oogenesis in Drosophila. J. Morph., 137, 29-48.

MARTíN-ALGANZA, A., CABRERO, J., LÓPEZ-LEÓN, M. D., PERfECTTI, F. AND CAMACHO, J. P. M. 1997. Super-

(c) The Genetical Society of Great Britain, Heredity, 80, 753-759. 
numerary heterochromatin does not affect several morphological and physiological traits in the grasshopper Eyprepocnemis plorans. Hereditas, 126, 187-189.

NUR, U. 1977. Maintenance of a "parasitic" B chromosome in the grasshopper Melanoplus femur-rubrum. Genetics, 87, 499-512.

Östergren, G. 1945. Parasitic nature of extra fragment chromosomes. Bot. Notiser, 2, 157-163.

PARDO, M. C., LÓPEZ-LEÓN, M. D., CABRERO, J. AND CAMACHO, J. P. M. 1994a. Transmission analysis of mitotically unstable B chromosomes in Locusta migratoria. Genome, 37, 1027-1034.

PARDO, M. C., CAMACHO, J. P. M. AND HEWITT, G. M. 1994b. Dynamics of ejaculate nutrient tranfer in Locusta migratoria. Heredity, 73, 190-197.

PARDO, M. C., LÓPEZ-LEÓN, M. D., VISERAS, E., CABRERO, J. AND CAMACHO, J. P. M. 1995. Mitotic instability of B chromosomes during embryo development in Locusta migratoria. Heredity, 74, 164-169.

SHAw, M. W. 1984. The population genetics of the B-chromosome polymorphism of Myrmeleotettix maculatus (Orthoptera: Acrididae). Biol. J. Linn. Soc., 23, $77-100$.

SHAw, M. W. AND HEWITT, G. M. 1990. B chromosomes, selfish DNA and theoretical models: where next? In: Futuyma, D. and Antonovics, J. (eds) Oxford Surveys in Evolutionary Biology, vol. 7, pp. 197-223. Oxford University Press, New York.

VISERAS, E. 1986. Análisis de la naturaleza, efectos y transmisión de los cromosomas accesorios de Locusta migratoria. Ph.D. Thesis, Universidad de Granada.

VISERAS, E., CAMACHO, J. P. M., CANO, M. I. AND SANTOS, J. L. 1990. Relationship between mitotic instability and accumulation of B chromosomes in males and females of Locusta migratoria. Genome, 33, 23-29. 